\title{
ХАРАКТЕРИСТИКА ВОЛЬЕРІВ ДЛЯ РАТИЧНИХ ARTIODACTYLA НА ТЕРИТОРІЇ ЖИТОМИРСЬКОЇ ОБЛАСТІ
}

\begin{abstract}
Досліджено стан вольєрного господарства Житомирської області. На 01.03.2018 р. на території області мисливське господарство веде 91 користувач, в 11 них функціонують вольєри. Їх загальна площа становить 941,7 га. Порівняно з 2007 р. площа вольєрів зросла у 8 разів. Найбільшими у регіоні $є$ вольєри ТОВ "Камія Плюс" (500,0 га) та СФГ "Земля Полісся" (228,0 га). Серед державних підприємств найбільші вольєри функціонують у ДП "Білокоровицьке ЛГ" (70,5 га) та ДП "Баранівське ЛМГ" (56,2 га). Ще три вольєри можна вважати (для Житомирської обл.) середніми, а саме: вольєр ТОВ "МК "Хантер" (40,0 га), ТОВ "УТМР" (29,0 га) та Житомирської ОО УТМР (12,0 га). Упродовж 2007-2017 рр. загальна площа вольєрів області істотно зросла. У 2007 р. вона становила 120,0 га, а на початок 2018 р. - 941,7 га. Завдяки будівництву у 2011 р. вольєра ТОВ "Камія Плюс" їх площа зросла більш ніж удвічі. На початку ХХІ ст. на території області існувало 4 вольєри (ДП "Баранівське ЛМГ", ДП "Радомишльське ЛМГ", СФГ "Земля Полісся" та МГ "В'юнки"), в яких утримували 46 особин Cervus nippon та 75 особин Sus scrofa. У 2017 р. чисельність основного поголів'я ратичних становила уже 561 особину 6 видів (Cervus elaphus (29,6 \%), Sus scrofa (20,0\%), Dama dama (19,3\%), Ovis ammon (18,2 \%), Cervus nippon (8,2 \%), Capreolus capreolus (4,8\%)). Якщо у 2013 р. більше половини всього поголів'я (52,4\%) становила Sus scrofa, то за два роки у 2016 р. - ії частка становила вже 40,0\%, а у 2018 р. - тільки 20,0 \%. Натомість частка Cervus elaphus за останні три роки у вольерах зросла від $15,3 \%$ до $29,6 \%$.
\end{abstract}

Ключові слова: мисливське господарство; напіввільне утримання; Sus scrofa; Cervus elaphus; Cervus elaphus; Dama dama.

Вступ. Ускладнення процесів взаємодії у системі дикі тварини - навколишне середовище - діяльність людини ставлять численні виклики перед популяціями ратичних тварин Свропи. Ріст чисельності та щільності тварин в умовах фрагментації природних стацій існування призводить до негативного їх впливу на сільське та лісове господарство (Apollonio et al., 2017). На цьому тлі швидкими темпами розвивається мисливське господарство, особливо у таких країнах, як Франція, Німеччина, Великобританія та Італія, а сучасна чисельність мисливців країн Європи становить понад 8 млн осіб (Khoietskyi \& Pokhaliuk, 2014). За таких обставин, однією 3 умов підвищення ефективності ведення мисливського господарства стало утримання тварин у напіввільних умовах, де площа вольєрів становить від декількох гектарів до декількох тисяч (Khoietskyi, et al., 2015). Розведення тварин на обмеженій території дає змогу досконаліше контролювати популяцію, що веде до значного зростання чисельності та якості поголів'я. Особливо це актуально для невеликих мисливських господарств, яких є більшість, де через обмеженість площі та придатних до проживання стацій дуже важко сформувати здорову, повноцінну популяцію.
На території України об'єктами вольєрного розведення серед ратичних є свиня дика (Sus scrofa Linnaeus, 1758), козуля європейська (Capreolus capreolus Linnaeus, 1758), олень благородний (Cervus elaphus Linnaeus, 1758), олень плямистий (Cervus nippon Temminck, 1838), лань (Dama dama Linnaeus, 1758), муфлон європейський (Ovis ammon Linnaeus, 1758), зубр (Bison bonasus Linnaeus, 1758) (Yevtushevskyi, 2009; Yevtushevskyi, 2012; Smagol \& Gavris, 2013), проте найперспективнішими видами вважають свиню дику, оленя благородного та плямистого, а також лань (Kaminetskyi et al., 2011).

Ратичні тварини є основними видами господарювання для більшості користувачів мисливських угідь Житомирської обл., а тому збільшення їх чисельності шляхом розведення у напіввільних умовах $є$ досить актуальним.

Мета роботи - з'ясувати сучасний стан ведення вольєрного господарства на території Житомирської області. Для досягнення поставленої мети потрібно виявити та проаналізувати наявні об'єкти напіввільного утримання ратичних тварин на території Житомирської обл.

Матеріали та методи дослідження. Аналіз стану

\section{Інформація про авторів:}

Кратюк Олександр Леонідович, канд. біол. наук, доцент кафедри експлуатації лісових pecypciв. Email: deneshi_ks@ukr.net Гузій Анатолій Ількович, д-р с.-г. наук, професор, завідувач кафедри експлуатації лісових pecypciв. Email: guziуai@ukr.net Власюк Володимир Павлович, канд. с.-г. наук, доцент кафедри експлуатації лісових pecypciв. Email: wlasyukvp@ukr.net Бездітко Людмила Володимирівна, канд. вет. наук, доцент кафедри екології лісу та безпеки життєдіяльності. Email: bezditkolv@ukr.net

Цитування за ДСту: Кратюк О. Л., Гузій А. І., Власюк В. П., Бездітко Л. В. Характеристика вольєрів для ратичних Artiodactyla на території Житомирської області. Науковий вісник НЛтУ України. 2018, т. 28, № 2. С. 50-53.

Citation APA: Kratiuk, O. L., Guziy, A. I., Vlasiuk, V. P., \& Bezditko, L. V. (2018). The Characteristic of Sanctuaries for Ungulates Artiodactyla on the Territory of Zhytomyr Region. Scientific Bulletin of UNFU, 28(2), 50-53. https://doi.org/10.15421/40280208 
вольєрного господарства Житомирської обл. здійснено на основі матеріалів Державної служби статистики України, Державного агентства лісових ресурсів України, а також проектів організації і розвитку мисливського господарства користувачів мисливських угідь Житомирської обл.

Результати дослідження та їх обговорення. Мисливське господарство в Житомирській обл. ведуть 91 користувач, а саме: 15 державних підприємств Житомирського обласного управління лісового та мисливського господарства, Житомирська обласна організація УТМР та 9 окремих районних організацій УТМР, ГО "Житомирська гарнізонна організація ТВМР ЗСУ", 66 інших користувачів.

Загальна площа закріплених мисливських угідь області становить 2131875 га, зокрема: лісових 887553 га, польових - 1131900 га, водно-болотних 112422 га. Мисливське господарство 15 державних підприємств управління займає площу 338096 га (15,9\% від загальної площі угідь області), УТМР в Житомирській обл. господарює на площі 1081899 га (50,7 \%), площа мисливських угідь ГО "Житомирська гарнізонна організація ТВМР ЗСУ" складає 18506 га (0,9\%), іншим користувачам надано 693374 га (32,5 \%).

На початку XXI ст. на території області існувало 4 вольєри у таких господарствах: ДП "Баранівське ЛМГ", ДП "Радомишльське ЛМГ", СФГ "Земля Полісся" та МГ "В'юнки". У них утримували 46 особин плямистого оленя та 75 особин свині дикої. Згодом чисельність вольєрів поступово зростала (рис. 1). Поправу найстаршим із теперішніх вольєрів можна вважати вольєр на території Явненського лісництва ДП "Баранівське ЛМГ". Його створено згідно з рішенням технічної ради Баранівського лісгоспзагу від 16.03.1985 р. на площі 56,2 га для розведення оленя плямистого 3 подальшим відловом та розселенням у мисливські угіддя України.

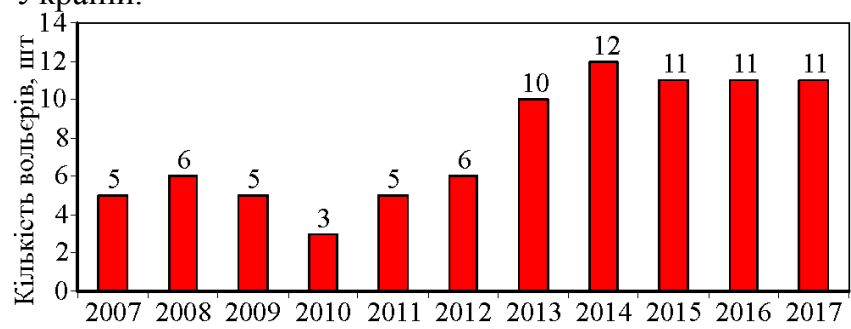

Рис. 1. Динаміка чисельності вольєрів на території Житомирської області

За офіційною статистикою на 01.03.2018 р. на території Житомирської обл. вольєри функціонують в 11 мисливських господарствах різних форм власності (табл.). У межах Польської зони функціонує 8 вольєрів, а у Лісостеповій частині області - 3 вольєри.

Загальна площа вольєрів становить 941,7 га. Найбільшим можна вважати вольєр ТОВ "Камія Плюс" площею 500 га. Іншим значним за площею $є$ вольєр СФГ "Земля Полісся" площею 228,0 га. Серед державних підприємств найбільші вольєри розташовані у ДП "Білокоровицьке ЛГ" (70,5 га) та ДП "Баранівське ЛМГ" (56,2 га). Ще три вольєри можна вважати (для Житомирської обл.) середніми, а саме: вольєр ТОВ "МК "Хантер" (40,0 га), ТОВ "УТМР" (29,0 га) та Житомирської ОО УТМР (12,0 га). Площа інших вольєрів не перевищує 2 га.
Табл. Характеристика вольєрів Житомирської області (на 01.03.2018 p.)

\begin{tabular}{|c|c|c|c|}
\hline Користувач & Вид тварин & $\begin{array}{c}\text { Площа } \\
\text { вольєра, } \\
\text { га }\end{array}$ & $\begin{array}{c}\text { Чисельність } \\
\text { основного } \\
\text { поголів'я, } \\
\text { особин }\end{array}$ \\
\hline \multicolumn{4}{|c|}{ Поліська зона } \\
\hline $\begin{array}{l}\text { ДП "Баранівсь- } \\
\text { ке ЛМГ" }\end{array}$ & Олень плямистий & 56,2 & 28 \\
\hline $\begin{array}{l}\text { ДП "Білокоро- } \\
\text { вицьке ЛГ" }\end{array}$ & Свиня дика & 70,5 & 23 \\
\hline \multirow{2}{*}{ TOB "УТМP" } & Олень плямистий & \multirow{2}{*}{29,0} & 9 \\
\hline & Лань & & 3 \\
\hline \multirow{2}{*}{\begin{tabular}{|l} 
ДП "Лугинське \\
ЛГ"
\end{tabular}} & Козуля європейська & 1,5 & 2 \\
\hline & Свиня дика & 1,5 & 3 \\
\hline \multirow{2}{*}{$\begin{array}{l}\text { Житомирська } \\
\text { ОО УТМР } \\
\text { СФГ "Земля По- } \\
\text { лісся" } \\
\end{array}$} & Свиня дика & 12,0 & 0 \\
\hline & $\begin{array}{l}\text { Олень європейсь- } \\
\text { кий }\end{array}$ & 228,0 & 45 \\
\hline \multirow{3}{*}{$\begin{array}{l}\text { ТОВ "МК "Хан- } \\
\text { тер" }\end{array}$} & $\begin{array}{l}\text { Олень європейсь- } \\
\text { кий }\end{array}$ & \multirow{3}{*}{40,0} & 26 \\
\hline & Лань & & 12 \\
\hline & $\begin{array}{l}\text { Муфлон європейсь- } \\
\text { кий }\end{array}$ & & 18 \\
\hline \multicolumn{2}{|c|}{ Разом по Поліській зоні } & 438,7 & 169 \\
\hline \multicolumn{4}{|c|}{$\begin{array}{l}\text { Лісостепова зона } \\
\end{array}$} \\
\hline \multirow{5}{*}{$\begin{array}{l}\text { TOB "КАMIA } \\
\text { ПЛЮС" }\end{array}$} & Олень європейський & \multirow{5}{*}{500,0} & 95 \\
\hline & Лань & & 90 \\
\hline & $\begin{array}{l}\text { Муфлон європейсь- } \\
\text { кий }\end{array}$ & & 84 \\
\hline & Свиня дика & & 77 \\
\hline & Козуля європейська & & 25 \\
\hline $\begin{array}{l}\text { ДП "Берди- } \\
\text { чівське ЛГ" }\end{array}$ & Свиня дика & 1,5 & 9 \\
\hline $\begin{array}{l}\text { ДП "Попіль- } \\
\text { нянське ЛГ" }\end{array}$ & Свиня дика & 1,5 & 0 \\
\hline \multicolumn{2}{|c|}{ Разом по Лісостеповій зоні } & 503,0 & 392 \\
\hline \multicolumn{2}{|c|}{ Всього } & 941,7 & 561 \\
\hline
\end{tabular}

За останні десять років загальна площа вольєрів області істотно зросла (рис. 2). Якщо у 2007 р. площа становила 120,0 га, то на початок 2018 р. - 941,7 га. Таке різке збільшення відбулося у 2011 р. зі створенням вольєра площею 500 га у ТОВ "Камія Плюс". Хотілося б зазначити, що загальна площа цього господарства становить 5709 га.

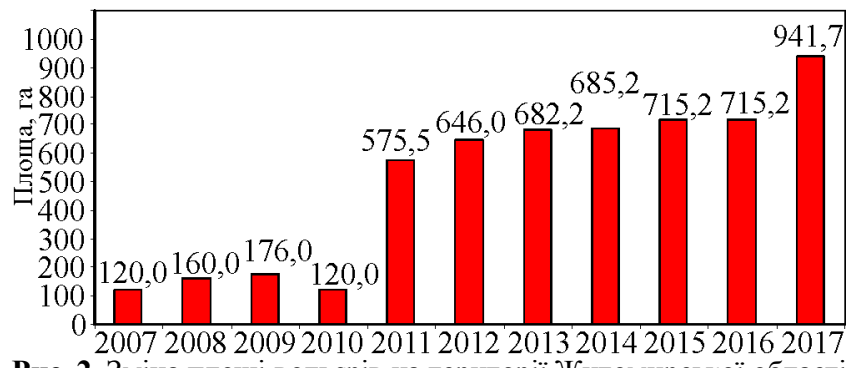

Рис. 2. Зміна площі вольєрів на території Житомирської області

Треба зауважити, що не всі наявні в області вольєри потрапляють в офіційну статистику. Вони зазвичай розташовані на території приватних мисливських господарств. Для таких об'єктів нагально стоїть питання контролю за виконанням наказу Міністерства охорони навколишнього природного середовища України 30.09.2010 № 429 "Порядок утримання та розведення диких тварин, які перебувають у стані неволі або в напіввільних умовах" та розпорядження Кабінету Міністрів України від 28.07.2010 № 1585-р "Про затвердження переліку нормативно-правових актів 3 питань захисту тварин від жорстокого поводження" та 3 метою утримання та розведення диких тварин, які перебувають у 
стані неволі або в напіввільних умовах, суб'єктами господарювання.

За останні роки чисельність тварин, які утримують у вольєрах, поступово зростає (рис. 3). У 2017 р. чисельність основного поголів'я ратичних становила 561 особину 6 видів. Така ситуація не є дивною, оскільки на 66 приватних користувачів припадає 693374 га мисливських угідь, що близько 10,5 тис. га на кожного. На такій обмеженій території важко забезпечити вільне стадо всім необхідним. Тому для якісного ведення мисливського господарства і збільшується чисельність тварин у вольєрах та кількість самих вольєрів.

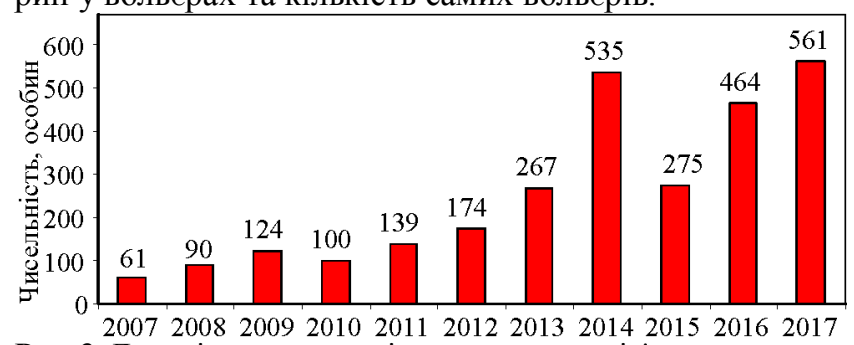

Рис. 3. Динаміка чисельності основного поголів'я ратичних тварин у вольєрах на території Житомирської області

Видовий склад ратичних тварин, яких утримують у напіввільних умовах, досить широкий: олень європейський, олень плямистий, свиня дика, козуля європейська, лань, муфлон європейський (рис. 4).

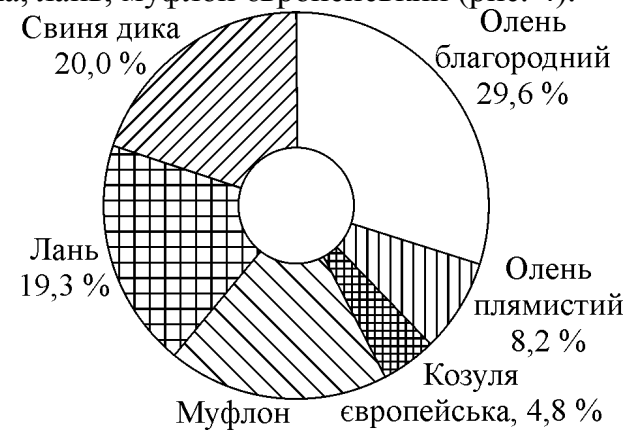

європейський, $18,2 \%$

Рис. 4. Видовий склад ратичних тварин у вольєрах на території Житомирської області (на 01.03.2018р.)

Якщо у 2013 р. більше половини всього поголів'я $(52,4 \%)$ становила свиня дика, то за два роки - у 2016 p. - пї частка становила вже 40,0 \% (Kratiuk, 2017), а у 2018 р. - тільки 20,0 \%. Це зумовлено непоодиноки- ми випадками захворювання на африканську чуму свиней. Користувачі поступово відмовляються утримувати проблемний вид і дедалі частіше віддають перевагу оленю благородному, частка якого у вольєрах за останні три роки зросла від 15,3\% до 29,6\%.

Висновки та перспективи подалыших досліджень. Вольєрне господарство на території Житомирської обл. має значні перспективи для подальшого розвитку, про що свідчить збільшення кількості вольєрів, їх площі, кількості тварин та їх видового складу. У перспективі потрібно встановити залежність між площею вольєрів, видовим складом тварин та станом лісових насаджень, а також розробити рекомендації щодо невиснажливого ведення вольєрного господарства в лісах.

\section{Перелік використаних джерел}

Apollonio, M., Belkin, V. V., Borkowski, J., et al. (2017). Challenges and science-based implications for modern management and conservation of European ungulate populations. Mammal Research, 62, 209-217. https://doi.org/10.1007/s13364-017-0321-5

Kaminetskyi, V. K., Babich, O. H., \& Smahol, V. M. (2011). Ekolohichni ta hospodarski aspekty napivvilnoho rozvedennia dykykh kopytnykh (na prykladi spetsializovanykh pidpryiemstv Derzhavnoho upravlinnia spravamy Prezydenta Ukrainy). Kyiv: ZAT "Myronivska drukarnia". [in Ukrainian].

Khoietskyi, P. B., \& Pokhaliuk, O. M. (2014). Myslyvske hospodarstvo krain Yevropy [World experience of captive hunting game management]. Scientific Bulletin of UNFU, 24(8), 42-52. [in Ukrainian].

Khoietskyi, P. B., Novak, A. A., \& Pokhaliuk, O. M. (2015). Svitovyi dosvid vedennia voliernoho myslyvskoho hospodarstva [Wildlife management in european countries]. Scientific Bulletin of UNFU, 25(3), 32-37. [in Ukrainian].

Kratiuk, O. L. (2017). Kharakterystyka voliernoho hospodarstva Zhytomyrskoi oblasti. Naukovi chytannia - 2017, 119-122. [in Ukrainian].

Smagol, V. N., \& Gavris, G. G. (2013). Zubr, Bison bonasus (Mammalia, Artiodactyla), v Ukraine: dinamika chislennosti, rasprostranenie, statcii i limitiruiushchie faktory [The wisent Bison bonasus (Mammalia, Artiodactyla) in Ukraine: dynamics of population, area of distribution, habitat and limiting factors]. Kyiv: Veles. [in Russian].

Yevtushevskyi, M. N. (2009). Pliamystyi olen (Servus nippon hertulorum Swinhoe, 1864) v Ukraini ta za yii mezhamy. Kyiv: Vyd. Dim "Eko-inform". [in Ukrainian].

Yevtushevskyi, M. N. (2012). Myslyvski tvaryny Ukrainy na voli ta v volierakh. Cherkasy: Vertykal. [in Ukrainian].

\section{А. Л. Кратюк, А. И. Гузий, В. П. Власюк, Л. В. Бездитко}

Житомирский национальный агроэкологический университет, г. Житомир, Украина

\section{ХАРАКТЕРИСТИКА ВОЛЬЕРОВ ДЛЯ КОПЫТНЫХ АRTIODACTYLA НА ТЕРРИТОРИИ ЖИТОМИРСКОЙ ОБЛАСТИ}

Исследовано состояние вольерного хозяйства Житомирской области. По состоянию на 01.03.2018 г. на территории области охотничье хозяйство ведут 91 пользователь, у 11 из них функционируют вольеры. Их общая площадь составляет 941,7 га. По сравнению с 2007 г. площадь вольеров возросла в 8 раз. Самыми большими в регионе есть вольеры ООО "Камия Плюс" (500,0 га) и СФХ "Земля Полесья" (228,0 га). Среди государственных предприятий наибольшие вольеры созданы в ГП "Билокоровицкое ЛХ" (70,5 га) и ГП "Барановское ЛОХ" (56,2 га). Еще три вольера можно считать (для Житомирской обл.) средними, а именно: вольер ООО "ОК "Хантер" (40,0 га), ООО "УООР" (29,0 га) и Житомирской ОО УТМР (12,0 га). На протяжении 2007-2017 гг. общая площадь вольеров области существенно возросла. В 2007 г. она составила 120,0 га, а на начало 2018 г. 941,7 га. Благодаря строительству в 2011 г. вольера ООО "Камия Плюс" их площадь возросла более чем в два раза. В начале XXI в. на территории области существовало 4 вольера (ГП "Барановское ЛОХ", ГП "Радомишльское ЛОХ", СФХ "Земля Полесья" та ОХ "Вьюнки"), в которых содержали 46 особей Cervus nippon и 75 Sus scrofa. В 2017 г. численность основного поголовья копытных составляла уже 561 особь 6 видов (Cervus elaphus (29,6\%), Sus scrofa (20,0\%), Dama dama (19,3\%), Ovis ammon (18,2\%), Cervus nippon (8,2\%), Capreolus capreolus (4,8 \%)). Если в 2013 г. больше половины всего поголовья (52,4 \%) составлял Sus scrofa, то за два года - в 2016 г. - его долевое участие составляло 40,0 \%, а в 2018 г. - всего лишь 20,0 \%. В то же время долевое участие Cervus elaphus за последние три года в вольерах возросло от 15,3\% до 29,6\%.

Ключевые слова: охотничье хозяйство; полувольное содержание; Sus scrofa; Cervus elaphus; Cervus elaphus; Dama dama. 


\section{THE CHARACTERISTIC OF SANCTUARIES FOR UNGULATES ARTIODACTYLA} ON THE TERRITORY OF ZHYTOMYR REGION

The raccoon animals are the main types of farming for the vast majority of users of hunting grounds in Zhytomyr oblast, and therefore increasing their number by breeding under semi-free conditions is very relevant. Characteristics of cages are made on the basis of materials from the State Statistics Service of Ukraine, the State Forestry Agency of Ukraine, as well as projects for the organization and development of hunting economy of users of hunting grounds in Zhytomyr region. Hunting economy is defined to be led by 91 users in the region. According to official statistics as of 01.03.2018, aviaries operate in 11 hunting farms of different forms of ownership in the territory of Zhytomyr region. Within Polish zone there are 8 enclosures, and in the forest-steppe part of the area 3 with a total area of 941.7 hectares. The largest is the open-air area "Kamia Plus" Ltd, with an area of 500 hectares. Another significant area is the enclosure SFG "Land Polissya" with an area of 228.0 hectares. Among the state enterprises, the largest enclosures are located in the State Enterprise "Belokorovitskaya LH" (70.5 hectares) and the "Baranivske LMG" (56.2 hectares). Three more aviaries can be considered (for Zhytomyr region) average, namely: the hangar of LLC "MK Hunter" (40.0 hectares), LLC "UTMS" (29.0 hectares) and Zhytomyr OS of UHFA (12.0 hectares). The area of the other cages does not exceed 2 hectares, and over the last ten years the total area of the cages has increased significantly, when in 2007 it amounted to 120.0 hectares or 941.7 hectares at the beginning of 2018. This sharp increase occurred in 2011 with the area of the cage 500 hectares at "Kamiya Plus" LLC. In recent years, the number of animals kept in the enclosures is gradually increasing. In 2013, more than half of all livestock (52.4\%) was Sus scrofa, then in two years - in 2016, its share was already $40.0 \%$, and in 2018 it was only $20.0 \%$, due to uncommon cases of African swine fever, users are gradually refusing to keep a problem and more and more often prefer Cervus elaphus, whose share in the cages over the past three years has increased from $15.3 \%$ to $29.6 \%$. Volunteer economy in Zhytomyr region has significant prospects for further development, as evidenced by the increase in the number of cages, their area, the number of animals and their species composition. In the long term, it is necessary to establish the relation between the area of the cages, the species composition of the animals and the state of the forest plantations, as well as to develop recommendations for the non-exhausting management of the covetry in the forests.

Keywords: hunting economy; half-free maintenance; Sus scrofa; Cervus elaphus; Cervus elaphus; Dama dama. 